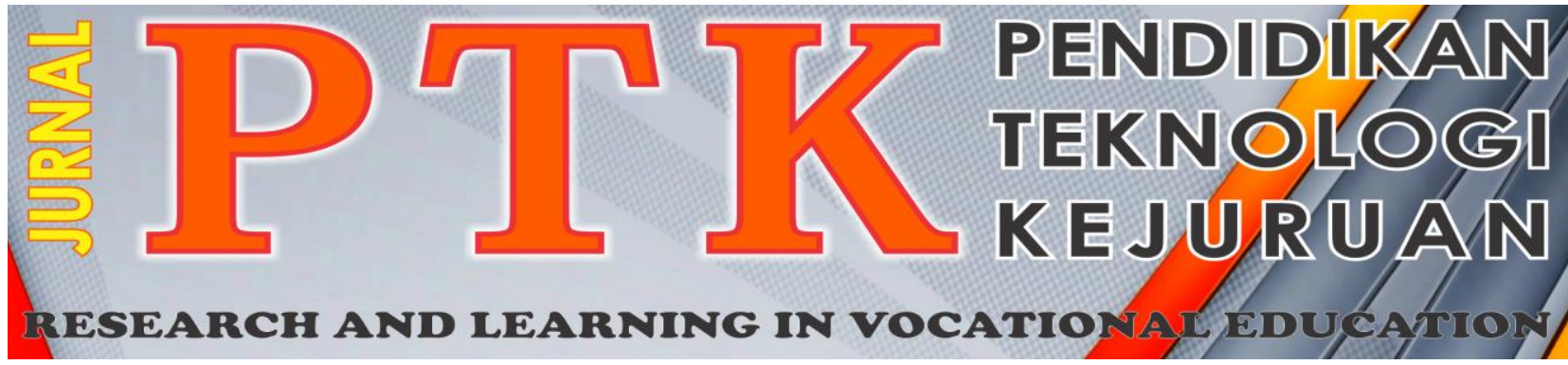

Vol. 2, No. 3, 2019

P-ISSN: 2621-3273

E-ISSN: 2621-1548

\title{
Pembuatan Yoghurt Susu Sapi Segar dengan Penambahan Puree Ubi Jalar Ungu
}

\author{
Sari Mustika ${ }^{1}$, Sedarnawati Yasni ${ }^{2}$, Suliantari $^{2}$ \\ ${ }^{1}$ Jurusan Ilmu Kesejahteraan Keluarga, Fakultas Pariwisata dan Perhotelan, Universitas Negeri Padang \\ ${ }^{2}$ Jurusan Ilmu Pangan Fakultas Teknologi Pertanian, Institut Pertanian Bogor \\ "Corresponding author, e-mail: sari.mustika@fpp.unp.ac.id ${ }^{1}$
}

\begin{abstract}
Abstrak - Pembuatan yoghurt susu sapi segar dengan penambahan puree ubi jalar ungu merupakan diversifikasi dalam pembuatan yoghurt. Tujuan dari penelitian ini adalah untuk menganalisis pengaruh penambahan puree ubi jalar ungu terhadap $\mathrm{pH}$, viskositas, total asam tertitrasi dan total padatan terlarut pada pembuatan yoghurt. Dalam penelitian ini digunakan rancangan percobaan RAL (rancangan acak lengkap) untuk pengujian terhadap $\mathrm{pH}$, viskositas, total asam tertitrasi dan total padatan terlarut dengan 3 perlakuan dan 2 ulangan, kemudian dilanjutkan dengan uji beda nyata Tukey jika terdapat hasil beda nyata pada setiap perlakuan. Perlakuan yang diberikan adalah penambahan puree ubi jalar ungu sebanyak $4 \%, 6 \%$ dan $8 \%$. Dari hasil penelitian, terpilih formula dengan penambahan puree ubi jalar ungu sebanyak $8 \%$ dengan karakteristik sebagai berikut: $\mathrm{pH} 4.14$, total asam tertitrasi $1.26 \%$, viskositas $1154.5 \mathrm{cp}$, total padatan terlarut $2.2^{\circ}$ Brix, dan total bakteri asam laktat $1.25 \times 10^{9} \mathrm{cfu} / \mathrm{ml}$.
\end{abstract}

Kata kunci : susu, yoghurt, ubi jalar ungu

\begin{abstract}
Making fresh cow's milk yogurt with the addition of purple sweet potato puree is diversification in making yogurt. The purpose of this study was to analyze the effect of adding purple sweet potato puree to $\mathrm{pH}$, viscosity, total titrated acid and total dissolved solids in yogurt making. In this study the RAL experimental design (complete random design) was used to test $\mathrm{pH}$, viscosity, total titrated acid and total dissolved solids with 3 treatments and 2 replications, then proceed with the Tukey real difference test if there were significant differences in each treatment. The treatment given is the addition of purple sweet potato puree as much as $4 \%, 6 \%$ and $8 \%$. From the research results, a formula with $8 \%$ purple sweet potato puree was selected with the following characteristics: $\mathrm{pH}$ 4.14, total titrated acid 1.26\%, viscosity $1154.5 \mathrm{cp}$, total dissolved solids 2.20 Brix, and total lactic acid bacteria $1.25 \times 109 \mathrm{cfu} / \mathrm{ml}$.
\end{abstract}

Keywords: milk, yogurt, purple sweet potato

\section{Pendahuluan}

Susu sapi segar didapatkan dengan cara pemerahan sapi perah. Hal ini dilakukan secara teratur dan terus menerus dan tanpa ada, pengurangan atau penambahan sesuatu. Susu segar mengandung nutrisi yang sangat baik untuk pertumbuhan mikroorganisme pembusuk. Oleh sebab itu, dalam rangka meningkatkan kualitas dan memperpanjang masa simpan dari susu segar perlu dilakukan pengolahan lebih lanjut sehinga kualitas dari susu dapat terjaga. Salah satu teknik pengolahan susu segar yang dapat dilakukan adalah dengan pembuatan susu fermentasi atau yang lebih dikenal dengan yoghurt. Yoghurt merupakan produk olahan susu dengan cara menambahkan bakteri asam laktat, yaitu Streptococcus thermophilus and Lactobacillus bulgaricus. Laktosa yang terkandung dalam susu akan dipecah menjadi glukosa dan galaktosa oleh bakteri asam laktat, hal ini akan membuat lebih mudah dicerna dan diserap oleh alat pencernaan manusia. Salah satu bahan pangan yang dapat ditambahkan dalam pembuatan yoghurt adalah puree ubi jalar ungu (Ipomoea batatas). Ubi jalar ungu tergolong ke dalam kelompok ubi-ubian dengan karakteristik warna ungu pada kulit dan warna buahnya.. Warna ungu dari ubi jalar menandakan kandungan pigmen antosianin yang sangat bermanfaat sebagai antioksidan pada tubuh manusia. Hasil penelitian Jawi dan Budiasa (2011) menunjukkan bahwa pemberian ekstrak air umbi jalar ungu pada kelinci yang diberikan makanan 
dengan kadar kolesterol yang tinggi dapat meningkatkan kadar total antioksidan dan memperbaiki profil lipid darah. Ubi jalar ungu mengandung oligosakarida yangt berfungsi sebagai prebiotik, karena tidak dicerna diantaranya rafinosa dan sukrosa yang mampu mendukung pertumbuhan atau aktifitas bakteri pencernaan secara selektif dan sekaligus meningkatkan kesehatan inangnya. Pada saat ini telah banyak dilakukan modifikasi pembuatan yoghurt dengan penambahan alami lainnya yang dapat meningkatkan nilai fungsi dari yoghurt itu sendiri. Hasil penelitian Abdul dkk., (2018) tentang pembuatan yoghurt dengan penambahan jagung manis menunjukkan bahwa penambahan susu sapi berpengaruh terhadap kadar asam laktat pada pembuatan yoghurt jagung manis oleh Streptococcus thermophillus dan Latobacillus bulgaricus. Pada penelitian lain Guruh dkk., (2017) tentang pembuatan yoghurt susu wijen dengan penambahan ekstrak buah bit menghasilkan yoghurt dengan karakteristik semakin tinggi jumlah penambahan biji wijen dan konsentrasi ekstrak buah bit maka aktivitas antioksidan, kadar protein, dan kadar gula total yoghurt yang dihasilkan juga akan semakin meningkat.

\section{METODE}

\section{A. Bahan dan Alat}

Bahan-bahan yang digunakan pada penelitian ini yaitu susu sapi segar yang berasal dari peternak di lingkungan Fakultas Peternakan IPB, susu skim (SUNLAC), ubi jalar ungu yang didapat dari Balai penelitian kacang-kacangan dan umbi-umbian (BALITKABI), Malang-Jawa Timur, gula pasir (Gulaku). Kultur bakteri yang dipakai pada penelitian ini adalah $S$. thermophillus FNCCI-903, $L$. bulgaricus FNCC004P. Untuk media tumbuh mikroorganisme digunakan MRSA (de Man Rogosa Sharpe Agar dari Oxoid) dan MRSB (de Man Rogosa Sharpe Broth dari Oxoid). Bahan kimia yang dipakai adalah $\mathrm{NaCl}$ (Oxoid), indikator phenolphtalein $1 \%, \mathrm{NaOH} 0,1 \quad \mathrm{~N}$. Alat yang digunakan dalam penelitian ini adalah $\mathrm{pH}$-meter, viskometer Brokfield, refraktometer, food processor, timbangan, panci, blender, sendok pengaduk, mikropipet, bunsen, magnetic stirrer, inkubator, autoclave, refrigerator, vorteks, laminar air flow, alat-alat gelas, waterbath, ose, cawan petridish.

\section{B. Metode}

Analisis yang digunakan pada penelitian ini adalah analisis ragam ANOVA dengan 3 perlakuan dan 2 ulangan dengan menggunakan software Minitab 16. Apabila hasil ANOVA menunjukkan adanya perbedaan pada perlakuan dilanjutkan dengan uji beda nyata. Penentuan produk yoghurt terpilih didasarkan pada hasil analisis $\mathrm{pH}$, total asam tertitrasi, viskositas, total padatan terlarut.

1. Persiapan Bahan Baku

Pembuatan puree ubi jakar ungu dilakukan dengan cara beberapa proses, yaitu ubi jalar ungu segar disortasi dan dicuci, dikukus selama 45 menit, dikupas, kemudian dihaluskan menggunakan food processor

\section{Pembuatan kultur starter}

Kultur starter dibuat dengan cara:larutan susu skim $12 \%$. Setelah dingin, larutan susu diinokulasikan dengan $1 \%$ kultur murni $S$. thermophillus FNCC1-903, L. bulgaricus FNCC004P, selanjutnya diinkubasi selama 24 jam pada suhu $37^{\circ} \mathrm{C}$.

3. Pembuatan yoghurt susu sapi segar dengan penambahan puree ubi jalar ungu

Pembuatan yohurt dilakukan dengan $3 \%$ susu skim dan 3\% sukrosa kedalam susu segar, lalu ditambahkan puree ubi jalar ungu $(4 \%, 6 \%, 8 \%)$ dan diaduk. Campuran dipanaskan suhu $90^{\circ} \mathrm{C}$ selama 30 menit, dan didinginkan sampai suhu mencapai $45^{\circ} \mathrm{C}$. Kemudian ditambahkan starter yoghurt sebanyak $2 \%$ dengan kombinasi starter yang terdiri dari $S$. thermophillus FNCC1-903 dan $L$. bulgaricus FNCC004P pada rasio 1:1 (v/v) dan dimasukkan kedalam wadah cup plastik serta diinkubasi pada suhu $37^{\circ} \mathrm{C}$ selama 24 jam.

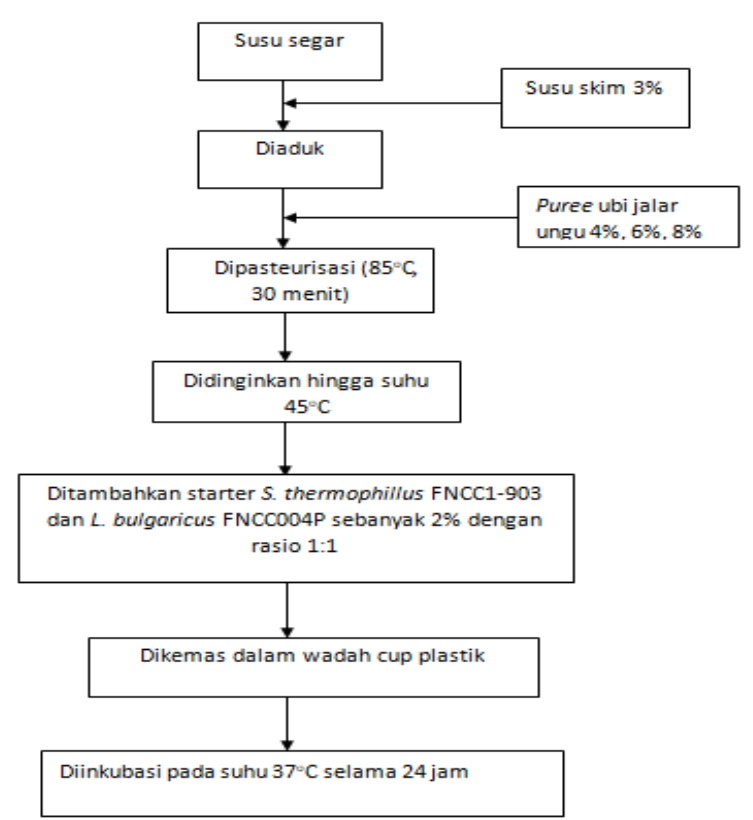

Gambar 1. Pembuatan yoghurt susu sapi segar dengan penambahan puree ubi jalar ungu

\section{Derajat keasaman yoghurt}

Sebelum dilakukan pengukuran derajat keasaman yoghurt, terlebih dahulu alat dikalibrasi dengan menggunakan larutan buffer yang mewakili

Jurnal PTK: Research and Learning in Vocational Education 
$\mathrm{pH}$ rendah (4.00) dan $\mathrm{pH}$ netral (7.00). Sampel ditempatkan dalam gelas piala $100 \mathrm{ml}$ sebanyak 25 $\mathrm{ml}$. Selanjutnya elektroda $\mathrm{pH}$ meter dimasukkan ke dalam sampel, dan nilai $\mathrm{pH}$ sampel dapat dibaca pada layar $\mathrm{pH}$ meter.

\section{Total asam tertitrasi}

Sampel sebanyak $10 \mathrm{ml}$ dimasukkan ke dalam tabung erlenmeyer, lalu teteskan 3 tetes indikator phenolphthalein $1 \%$. Sampel dititrasi dengan larutan $\mathrm{NaOH} \quad 0.1 \mathrm{~N}$ yang telah terstandarisasi sampai terbentuk warna merah muda yang merupakan titik akhir titrasi Perhitungan total asam tertitrasi dapat dihitung dengan persamaan (1) :

Total Asam Laktat $(\%)=$ V NaoH x N NaOH x 90 x 100

V sampel x 1000

\section{Viskositas}

Analisa viskositas dilakukan dengan menggunakan alat viskometer Brokfield. Sampel sebanyak $200 \mathrm{ml}$ dimasukkan ke dalam gelas piala $250 \mathrm{ml}$. Celupkan spindel ke dalam sampel lalu atur ketinggian viscometer hingga tanda garis tercelup. Lakukan pengukuran dengan cara menekan tombol ON dan biarkan spindel berputar selama 20 -30 detik, dan baca angka yang ditunjuk spindel dengan tepat.

\section{Total padatan terlarut}

Ambil sampel dengan menggunakan pipet tetes dan letakkan didalam prisma refraktometer. Nilai hasil pengukuran ditentukan dengan melihat skala yang tertera pada refraktometer.

\section{HASIL DAN PEMBaHASAN}

Pembuatan yoghurt dilakukan dengan menambahkan $2 \%$ kultur bakteri asam laktat campuran $S$. thermophillus FNCC1-903 dan $L$. bulgaricus FNCC004P dengan rasio 1:1 (v/v) dan puree ubi jalar ungu dengan tiga konsentrasi berbeda $(4 \%, 6 \%, 8 \%)$. Hasil analisa fisikokimia yoghurt yang dihasilkan dapat dilihat pada Tabel 1.

Tabel 1 Hasil pengukuran analisa fisikokimia

\begin{tabular}{lcccc}
\hline $\begin{array}{l}\text { Konsentrasi } \\
\text { Puree (\%) }\end{array}$ & $\mathrm{pH}$ & Viskositas (cp) & $\begin{array}{c}\text { Total Asam } \\
\text { Tertitasi } \\
(\%)\end{array}$ & $\begin{array}{c}\text { Total Padatan } \\
\text { Terlarut ('Brix) }\end{array}$ \\
\hline 4 & $4.28 \pm 0.011^{\mathrm{a}}$ & $718 \pm 108.9^{\mathrm{ab}}$ & $1.16 \pm 0.04^{\mathrm{a}}$ & $11.9 \pm 0.14^{\mathrm{a}}$ \\
6 & $4.22 \pm 0.004^{\mathrm{\omega}}$ & $822.5 \pm 92.6^{\mathrm{ab}}$ & $1.25 \pm 0.00^{\mathrm{a}}$ & $12.1 \pm 0.21^{\mathrm{a}}$ \\
8 & $4.14 \pm 0.007^{\mathrm{b}}$ & $1154.5 \pm 231.2^{\mathrm{a}}$ & $1.26 \pm 0.07^{\mathrm{a}}$ & $12.2 \pm 0.07^{\mathrm{a}}$ \\
\hline
\end{tabular}

Keterangan: $*$ nilai $=$ rata-rata \pm standar deviasi dengan dua kali ulangan $(\mathrm{n}=2)$

* angka-angka pada kolom yang sama yang diikuti huruf yang berbeda menunjukkan beda nyata pada taraf 5\% (uji beda nyata Tukey)
Tabel 1 menunjukkan bahwa nilai $\mathrm{pH}$ yoghurt yang dihasilkan adalah 4.14-4.59. Hasil penelitian menunjukkan semakin banyak jumlah puree yang ditambahkan nilai $\mathrm{pH}$ semakin rendah. Nilai $\mathrm{pH}$ yoghurt paling rendah ditunjukkan oleh yoghurt dengan penambahan puree ubi jalar ungu sebesar $8 \%$, sedangkan nilai $\mathrm{pH}$ yoghurt paling tinggi ditunjukkan pada yoghurt dengan penambahan puree ubi jalar ungu sebanyak 4\%. Adanya aktivitas kultur starter mengubah laktosa menjadi asam laktat yang menyebabkan terjadinya perubahan nilai $\mathrm{pH}$. Hal ini didukung oleh Leroy dan Vuyst (2004) yang menjelaskan perubahan laktosa dalam produksi yoghurt oleh kultur starter menjadi asam laktat menyebabkan kisaran $\mathrm{pH}$ 4.2-4.5 dan selama penyimpanan $\mathrm{pH}$ dapat menurun hingga mencapai 4.0.

Dalam proses fermentasi bakteri asam laktat berperan memfermentasi karbohidrat yang ada yang akan menghasilkan asam laktat. Asam laktat yang terbentuk inilah yang akan mengakibatkan turunnya nilai $\mathrm{pH}$ yang mengindikasikan terjadinya peningkatan keasaman pada produk. Streptococus berperan dalam menurunkan $\mathrm{pH}$ pada awal campuran yogurt sekitar 5.0, selanjutnya Lactobacillus berperan untuk penurunan $\mathrm{pH}$ lebih lanjut menjadi $\mathrm{pH} 4.5$.

Menurut Aswal et al. (2012) yoghurt yang siap untuk dimakan mempunyai $\mathrm{pH}$ 4.0. Nilai $\mathrm{pH}$ yang didapatkan pada penelitian ini lebih tinggi apabila dibandingkan dengan hasil penelitian Sayuti et al. (2013) dalam pembuatan yoghurt jagung manis dengan menggunakan kultur starter L. acidophilus dan Bifidobacterium sp serta penambahan ekstrak ubi jalar ungu sebanyak $15 \%$ yang mempunyai $\mathrm{pH}$ 3.6. Karena adanya akumulasi asam laktat yang merupakan hasil utama dari aktifitas bakteri selama proses fermentasi maka mengakibatkan terjadinya penurunan $\mathrm{pH}$. Proses fermentasi oleh bakteri asam laktat menyebabkan jumlah ion $\mathrm{H}^{+}$yang terdisosiasi meningkat sehingga terjadi penurunan $\mathrm{pH}$ yang kemudian akan menghasilkan rasa asam. Penelitian Devangga, dkk., (2018) menunjukkan hasil bahwa penambahan tepung ubi jalar ungu pada produk yoghurt dapat meningkatkan aktivitas antioksidan dan $\mathrm{pH}$ produk yang tidak berubah. Semakin tinggi konsentrasi tepung ubi jalar ungu yang diberikan dapat meningkatkan viskositas produk.

Total asam tertitrasi diartikan sebagai total asam laktat yang dihasilkan pada saat proses fermentasi yang merupakan hasil perombakan laktosa oleh bakteri asam laktat. Hasil analisa menunjukkan nilai total asam tertitrasi yang dihasilkan berkisar pada rentang 1.16\%-1.39\%. Hal ini telah memenuhi persyaratan mutu yoghurt menurut SNI (2009), yaitu $0.5 \%-2.0 \%$. Nilai total 
asam tertitrasi tertinggi dihasilkan pada yoghurt dengan penambahan puree ubi jalar ungu sebanyak $8 \%$, dan nilai total asam tertitrasi terendah dihasilkan pada yoghurt dengan penambahan puree ubi jalar ungu sebanyak 4\%. Hasil penelitian (Tabel 1) menunjukkan jumlah asam yang dihasilkan semakin meningkat seiring dengan meningkatnya penambahan puree ubi jalar ungu, meskipun dari analisis statistik penambahan konsentrasi puree ubi ungu sebanyak 4\%, 6\%, $8 \%$ tidak berbeda nyata terhadap total asam tertitrasi yang diperoleh. Hal ini diduga karena konsentrasi puree ubi jalar ungu yang digunakan tidak jauh berbeda sehingga jumlah asam laktat yang terbentuk selama proses fermentasi dihasilkan tidak terlalu berbeda. Dari hasil penelitian ini menunjukkan nilai total asam tertitrasi berbanding terbalik dengan nilai $\mathrm{pH}$. Semakin tinggi nilai total asam tertitrasi maka nilai $\mathrm{pH}$ akan semakin rendah. Meningkatnya konsentrasi puree ubi jalar ungu yang diberikan maka nilai $\mathrm{pH}$ akan semakin menurun dan nilai total asam tertitrasi semakin meningkat. Hal ini diduga karena dengan peningkatan konsentrasi puree ubi jalar ungu, maka semakin banyak sumber nutrien (oligosakarida) bagi S. thermophillus FNCC1-903 dan L. bulgaricus FNCC004P dalam proses fermentasi.

Hasil penelitian sejalan dengan penelitian Sayuti et al. (2013) yaitu penambahan ekstrak ubi jalar ungu sebanyak 15\% pada pembuatan yoghurt jagung manis dengan menggunakan kultur starter $L$. acidophilus dan Bifidobacterium sp. menghasilkan total asam tertitrasi $1.22 \%$. Peningkatan jumlah asam laktat yoghurt diikuti dengan penurunan nilai $\mathrm{pH}$. Bakteri asam laktat memproduksi sejumlah asam laktat dari fermentasi substrat (karbohidrat). Asam laktat tersebut akan menyebabkan penurunan nilai $\mathrm{pH}$ dan menyebabkan timbulnya rasa asam.

Pengukuran viskositas yoghurt (Tabel 1) dihasilkan nilai viskositas berkisar pada rentang 416-1154.5. Dari Tabel 1 dapat dilihat semakin tinggi konsentrasi puree ubi jalar ungu yang diberikan akan meningkatlan viskositas yoghurt yang dihasilkan. Nilai viskositas terendah ditunjukkan pada yoghurt dengan penambahan puree ubi jalar ungu sebanyak $4 \%$, dan nilai viskositas tertinggi ditunjukkan pada yoghurt dengan penambahan $8 \%$ puree ubi jalar ungu. Hasil analisa statistik menunjukkan pemberian puree ubi jalar ungu sebanyak $4 \%$ dan $6 \%$ tidak berbeda nyata dan memberikan hasil yang berbeda pada pemberian puree ubi jalar ungu sebanyak $8 \%$. Hal ini berarti bahwa pemberian puree ubi jalar ungu sebanyak $4 \%$ dan $6 \%$ menghasilkan viskositas yoghurt yang hampir sama, sedangkan pemberian puree ubi jalar ungu sebanyak $8 \%$ menyebabkan terjadinya peningkatan viskositas atau yoghurt yang dihasilkan semakin mengental. Menurut Karinawatie et al. (2008) peningkatan viskositas selama fermentasi terjadi akibat penurunan $\mathrm{pH}$ yang menyebabkan penggumpalan kasein (protein susu) dan membentuk gel. Pembentukan gel inilah yang menyebabkan terjadinya peningkatan viskositas dan yoghurt yang dihasilkan akan menjadi kental. Selain itu pembentukan viskositas juga disebabkan adanya penambahan pati (puree ubi jalar ungu). Pati bersifat sebagai bahan pengental yang dapat mengikat air. Semakin banyak pati yang ditambahkan, maka kapasitas pengikatan air juga akan semakin meningkat yang akhirnya akan meningkatkan kekentalan yoghurt yang dihasilkan.

Hasil statistik menunjukkan bahwa pemberian puree ubi jalar ungu sebanyak $8 \%$ dalam pembuatan yoghurt tidak mempengaruhi total padatan terlarut produk. Hasil pengukuran (Tabel 1) menunjukkan nilai total padatan terlarut yang dihasilkan berkisar pada rentang 11.1-12.2 dan nilai tersebut sudah memenuhi persyaratan mutu yoghurt berdasarkan SNI (2009) yaitu nilai total padatan terlarut minimal 8.2. Selama penyimpanan nilai total padatan terlarut dapat semakin menurun yang disebabkan adanya aktivitas bakteri asam laktat dalam merombak gulagula sederhana yang ada pada yoghurt (Kusuma 2007). Berdasarkan pengukuran fisikokimia pada pembuatan yoghurt dengan campuran susu sapi dan puree ubi jalar ungu dengan konsentrasi $(4 \%, 6 \%$, $8 \%$ ) diambil kesimpulan bahwa yoghurt dengan penambahan puree ubi jalar ungu sebanyak $8 \%$ merupakan formula terpilih. Pengambilan kesimpulan ini didasarkan dengan melihat hasil analisa $\mathrm{pH}$ dan viskositas, dimana yoghurt dengan penambahan puree sebanyak $8 \%$ memiliki nilai $\mathrm{pH}$ terendah (4.14) dan nilai viksositas tertinggi (1154.5 cp).

\section{Total Bakteri Asam Laktat}

Pada yoghurt formula dasar terpilih yaitu yoghurt dengan penambahan puree ubi jalar ungu sebanyak $8 \%$ dilakukan perhitungan total bakteri asam laktat. Hasil total bakteri asam laktat yang terdapat dalam yoghurt dengan penambahan puree ubi jalar ungu sebanyak $8 \%$ pada penelitian ini sebanyak $1.25 \times 10^{9} \mathrm{cfu} / \mathrm{ml}$. Hasil ini menunjukkan bahwa yoghurt yang dihasilkan sudah dapat disebut sebagai minuman kesehatan, sesuai dengan Ananta et al. (2005) yang menyatakan minimal konsumsi harian $10^{8}$ sel untuk memastikan efek probiotik pada kesehatan. Pertumbuhan bakteri asam laktat dipengaruhi oleh beberapa hal antara lain nutrisi, temperatur, kelembaban, oksigen, $\mathrm{pH}$, dan substansi penghambat. Nutrisi yang dimaksud adalah laktosa dan protein yang merupakan sumber karbon dan sumber nitrogen yang berasal dari susu yang dibutuhkan untuk pertumbuhan bakteri asam laktat. Bakteri asam laktat membutuhkan sumber energi 
dan karbon yang terkandung dalam susu dan puree ubi jalar ungu. Selain itu kandungan nitrogen yang terdapat dalam protein susu dapat menyebabkan pertumbuhan bakteri asam laktat lebih cepat dan meningkat (Karinawatie et al. 2008) .

Menurut Wardani dalam Tari, dkk., (2018), konsumsi yoghurt dengan suplementasi prebiotik seperti ubi jalar ungu ditengarai memberi manfaat besar bagi kesehatan tubuh. Oligosakarida pada ubi jalar sebagian besar terdiri dari rafinosa dan stakhiosa yang tidak dapat dicerna, namun akan difermentasi oleh bakteri-bakteri Streptococcus thermophillus dan Lactobacillus bulgaricus dengan cara meningkatkan kemampuan hidup dan sistem pencernaan. Dari hasil penelitian Tari, dkk., (2018) menunjukkan hasil penelitian bahwa pemberian yoghurt prebiotic seperti ubi jalar ungu berpengaruh nyata terhadap performa hewan coba yang terdiri dari nilai protein efficiency ratio, efisiensi pakan, berat badan, konsumsi pakan dan kadar air faeses.

\section{KESIMPULAN}

Yoghurt susu sapi segar dengan penambahan puree ubi jalar ungu sebanyak 8\% memiliki karakteristik sebagai berikut: $\mathrm{pH} 4.14$, total asam tertitrasi $1.26 \%$, viskositas $1154.5 \mathrm{cp}$, total padatan terlarut $2.2^{\circ}$ Brix, total bakteri asam laktat $1.25 \times 10^{9}$ $\mathrm{cfu} / \mathrm{ml}$

\section{DAfTAR Pustaka}

[1] Abdul, A., Kumaji, S. And Duengo, F., 2018. Pengaruh Penambahan Susu Sapi Terhadap Kadar Asam Laktat Pada Pembuatan Yoghurt Jagung Manis Oleh Streptococcus Thermophillus Dan Lactobacillus Bulgaricus. Bioma: Jurnal Biologi Makassar, 3(2), Pp.1-9.

[2] Ananta E, Volkert M, Knorr D. 2005. Cellular injuries and storage stability of spray-dried Lactobacillus rhamnosus GG. International Dairy J. 15:399-409.

[3] Aswal P, Priyadarsi S, Anubha S. 2012. Yoghurt preparation, characterstic and recent advencements. Cibtech J of Bioprotocols. 23193840 .

[4] Devangga, F., 2019. Optimasi Persentase Penggunaan Tepung Ubi Jalar Ungu (Ipomoea batatas L. Poir) pada Yoghurt Berdasarkan Parameter Aktivitas Antioksidan, Derajat Keasaman, Viskositas dan Mutu Hedonik. Jurnal Teknologi Pangan, 3(1).
[5] Guruh, M.K. And Suhartatik, N., 2017. Karakteristik Yoghurt Susu Wijen (Sesamun Indicum) Dengan Penambahan Ekstrak Buah Bit (Beta Vulgaris). Jurnal Teknologi Dan Industri Pangan, 3(2).

[6] Jawi IM, Budiasa K. 2011. Ekstrak air umbi ubi jalar ungu menurunkan total kolesterol serta meningkatkan total antioksidan darah kelinci. $J$ Veteriner. 12(2):120-125.

[7] Karinawatie S, Kusnadi J, Martati E. 2008. Efektivitas konsentrat protein whey dan dekstrin untuk mempertahankan viabilitas bakteri asam laktat dalam starter kering beku yoghurt. $J$ Teknologi Pertanian. 9(2):121-180.

[8] Kusuma MH. 2007. Pembuatan yoghurt ubi jalar (Ipomea batatas L.) menggunakan kultur campuran bakteri asam laktat [skripsi]. Bogor (ID). Institut Pertanian Bogor.

[9] Leroy F, Vuyst LD. 2004. Lactic acid bacteriaas functional starter cultures for the food fermentation industry. Trends in Food Science \& Technology. 15:67-78.

[10] Sayuti I, Wulandari S, Sari DK. 2013. Efektivitas penambahan ekstrak ubi jalar ungu (Ipomea batatas var. Ayamurasaki) dan susu skim terhadap kadar asam laktat dan $\mathrm{pH}$ yoghurt jagung manis (Zea mays L. Saccharata) dengan menggunakan inokulum Lactobacillus acidophilus dan Bifidobacterium sp. J Biogenesis. 9(2): 21- 27.

[11] [SNI] Standar Nasional Indonesia. 2009. Syarat mutu yoghurt SNI 2981-2009. Jakarta (ID) : Badan Standarisasi Nasional.

[12] Tari, A. I. N., \& Hartati, S. (2018). Performa Kesehatan Tikus Sprague Dawley Akibat Pemberian Yoghurt Prebiotik Sebagai Antidiare. Jurnal Ilmiah Teknosains, 4(2).

\section{Biodata Penulis}

Sari mustika, lahir di Lubuk Sikapinh 9 Juni 1989. Sarjana Peternakan di Program Studi Teknologi Hasil Ternak Jurusan Produksi Ternak Fakultas Peternakan Universitas Andalas. Tahun 2015 memperoleh gelas Magister Sains di jurusan Ilmu Pangan Program Pascasarjana Institut Pertanian Bogor . Staf pengajar di jurusan Ilmu Kesejahteraan Keluarga FPP UNP sejak tahun 2017 sampai sekarang. 